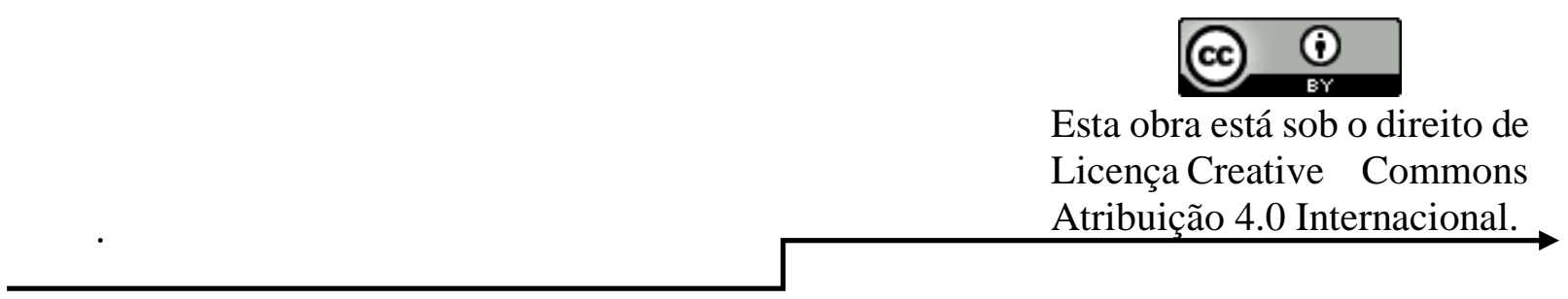

\title{
A QUESTÃO MULTICULTURAL NO ESPAÇO ESCOLAR: DESAFIOS PARA AS PRÁTICAS PEDAGÓGICAS
}

\author{
Márcia Lúcia Costa da Silval \\ Andrea Marques Vanderlei Fregadolli ${ }^{2}$ \\ Betijane Soares de Barros ${ }^{3}$ \\ Marta Lucia Silva Costa ${ }^{4}$
}

\section{RESUMO}

Introdução: a perspectiva do multiculturalismo surge como uma ideologia que defende uma educação em que a diversidade não é somente constatada, mas também incluída e valorizada no currículo e nas práticas pedagógicas, de modo que o papel do professor se torna crucial, de mediação, para uma inter-relação entre as diferentes culturas existentes na escola. Objetivo: analisar a questão multicultural no espaço escolar a fim de compreender as abordagens e perspectivas para os povos indígenas. Metodologia: revisão bibliográfica do tipo sistemática integrativa. Resultados e Discussão: Considerando os critérios de inclusão estabelecidos durante a pesquisa foram selecionados 24 artigos que contemplaram duas categorias: a diversidade na sala de aula: implicações para as práticas pedagógicas; a educação para os povos indígenas sob a perspectiva multicultural. Conclusão: O multiculturalismo abre espaço para a vontade de cada indivíduo e de cada grupo em mostrar sua identidade aos outros; e todos, em conjunto, promovem e alcançam o interculturalismo, que pelo diálogo, pela troca de conhecimentos, práticas e comportamentos, integra essas vontades com o objetivo de promover a compreensão e a tolerância entre os indivíduos de origens diversas. A educação multicultural, mais especificamente, deve promover a partilha, a valorização e o respeito pela diversidade das culturas representadas na turma, na escola e na comunidade, assim como combater os preconceitos e as discriminações étnicas.

Descritores: Multiculturalismo. Pluralidade. Diversidade. Educação multicultural. Educação escolar indígena.

\begin{abstract}
\footnotetext{
1 marciamg@live.com

2 deadoutorado@hotmail.com

3 bj-sb@hotmail.com

4 martaluciadir@gmail.com
}

Introduction: the perspective of multiculturalism emerges as an ideology that defends an education in which diversity is not only seen, but also included and valued in the curriculum and pedagogical practices, so that the role of the teacher becomes crucial, of mediation, for an interrelation between the different cultures existing in the school. Goal: to analyze the multicultural issue in the school space in order to understand the approaches and perspectives 
for indigenous peoples. Methodology: bibliographic review of the integrative systematic type. Results and Discussion: Considering the inclusion criteria established during the research, 24 articles were selected that contemplated two categories: diversity in the classroom: implications for pedagogical practices; education for indigenous peoples from a multicultural perspective. Conclusion: Multiculturalism makes room for the will of each individual and each group to show their identity to others; and all, together, promote and achieve interculturalism, which through dialogue, through the exchange of knowledge, practices and behaviors, integrates these wills with the aim of promoting understanding and tolerance among individuals of different origins. Multicultural education, more specifically, should promote sharing, appreciation and respect for the diversity of cultures represented in the class, at school and in the community, as well as combating prejudice and ethnic discrimination.

Descriptors: Multiculturalism. Plurality. Diversity. Multicultural education. Indigenous school education. 


\section{INTRODUÇÃO}

A diversidade cultural é um fato inquestionável de nossas sociedades, e posto que a cultura também inclui, entre outros aspectos, tradições religiosas e elementos de identidade, torna-se evidente a necessidade de pensar outras maneiras de convivência, ou de transformar as atuais maneiras, entre as diversas culturas que compartilham os mesmos marco espaçotemporais (CHICARINO, 2017). Já que nem todas as culturas estão em um plano de igualdade, é possível falar de identidades deslocadas ou também de culturas hegemônicas ou dominantes.

A cultura, em seu conceito teórico mais difundido, envolve o conjunto complexo de crenças, costumes, conhecimentos, hábitos e tradições compartilhadas pelos membros de uma sociedade, transmitidos de geração em geração (CANDAU, 2014). Hoje, devem estar implícitas as transformações constantes que os grupos minoritários trazem consigo e propagam no mundo. Assim, pensar a diversidade é interpelar a pluralidade, interrogando o lugar que essa pluralidade implica no contexto da educação. Dialogar com a diversidade é ter consciência de que o outro não pode ser reduzido à lógica do mesmo. É compreender a necessidade de preservar o outro em suas diferenças e em sua dignidade como pessoa (CHICARINO, 2017).

De acordo com Freitas de Lima (2014), uma proposta de convivência entre culturas provem do que se denomina multiculturalismo e interculturalismo, que em traços gerais diz respeito a individualidades e universalidades humanoculturais, promovidas no convívio comunitário em um intercâmbio constante. Tal convivência advoga pela inclusão de todos os cidadãos, seja na cultura, seja na vida democrática, além de ser propulsora de uma cultura de paz.

Bavaresco; Tacca (2016, p. 610) defende que "o multiculturalismo é a valorização da diversidade cultural que busca eliminar preconceitos e estereótipos construídos historicamente, procurando formar uma sociedade alicerçada no respeito e dignidade do outro com suas diferenças".

A perspectiva intercultural, por sua vez, surge como um prolongamento do multiculturalismo. Essa perspectiva vai além da convivência entre culturas, pois abrange aspectos como a identidade e o respeito na condição de caminho para o bem comum (FREITAS DE LIMA, 2014).

Vale a pena caracterizar 0 multiculturalismo e o interculturalismo, diferenciando-os e observando como ambos estão associados. O primeiro pressupõe a 
coexistência das culturas dos diversos grupos étnicos na sociedade. Os indivíduos mantêm suas identidades culturais, ou seja, a liberdade de participar em uma vida cultural e social própria, em circunstâncias iguais às das outras culturas. Essa coexistência desenvolve a igualdade de oportunidades das minorias e tem em conta os seguintes objetivos: aquisição de conhecimentos e competências necessárias à participação na cultura cívica nacional e à adesão aos ideais democráticos da igualdade, da justiça e da liberdade; afirmação dos aspectos mais importantes e identificadores da cultura materna do indivíduo; e participação ativa das famílias dos alunos na comunidade escolar (FREITAS DE LIMA, 2014).

$\mathrm{O}$ interculturalismo significa um duplo movimento de afirmação de cada cultura e abertura às outras culturas. Assim, as culturas tentam encontrar pontos comuns para se complementarem e enriquecerem umas às outras. Visa ainda a um conjunto de processos gerados pelas interações entre culturas em uma relação de trocas recíprocas.

No caso das escolas, desenvolve-se um clima de respeito e abertura a diversidade e transmissão de culturas. Os alunos e todos os outros agentes passam a ter uma vida rica em valores e conhecimentos culturais. $\mathrm{O}$ processo assenta-se na assimilação e na integração de novas atitudes, com destaque para a comunicação com o outro e a aceitação e valorização daquele que é diferente (FREITAS DE LIMA, 2014). Portanto, a educação será intercultural desde que potencialize a inter-relação entre as pessoas de distintas culturas e origens sociais.

A diversidade cultural, expressa na multiplicidade de fenômenos, desde fluxos migratórios e intercâmbios promovidos pela globalização até nacionalismos fundamentalistas, processos de exclusão social a partir da diferença e movimentos étnicos de vários tipos, desafiou a modernidade com base na correspondência entre um Estado e uma cultura nacional (CHICARINO, 2017). Atualmente, aceitase que a maioria dos Estados são plurinacionais, lugar de mais de uma cultura nacional e internacional, e pluriculturais, uma vez que apresentam e convivem com diferentes expressões de diversidade. Portanto, são necessários arranjos políticos, educacionais, sociais e humanos que facilitam a mútua compreensão e uma existência democrática e cidadã (CILIATO; SARTORI, 2015).

Desse modo, a perspectiva do multiculturalismo surge como uma ideologia que defende uma educação em que a diversidade não é somente constatada, mas também incluída e valorizada no 
currículo e nas práticas pedagógicas, de modo que o papel do professor se torna crucial, de mediação, para uma interrelação entre as diferentes culturas existentes na escola. "Portanto, é preciso pensar nas diferenças dentro de suas “diferenças", e o multiculturalismo abre espaço para refletir a complexidade e as divergências classificatórias da atualidade" (BAVARESCO; TACCA, 2016, p. 61).

Nesse sentido, concorda-se com Domingues; Cota (2014, p. 11) quando afirmam que referente ao processo de ensino aprendizagem "o destaque é atribuído à valorização da cultura do indivíduo, conferindo significado ao que lhe é proposto. [...] com o objetivo de desenvolver uma educação crítica para a superação da desigualdade e exclusão social e do modelo monocultural e hegemônico de educação". Dessa forma, entende-se que a educação precisa ajudar a gerar o ânimo e a confiança nas microculturas existentes, respeitando suas tradições, sua identidade cultural ou local, uma vez que é todo o conjunto de conhecimentos e modos de agir e pensar que enriquece o indivíduo como ser humano. Entretanto, o que se percebe comumente é que nem sempre a escola cumpre com essa premissa, de modo que a integração se faz, muitas vezes, ainda com base na aculturação. Diante dessa realidade faz-se necessário compreendê-la e transformá-la para a plena inclusão e êxito dos alunos, seja lá qual for sua etnia ou sua origem social (DOMINGUES; COTA, 2014).

Com isso, partindo da premissa de que a questão multicultural acontece a partir das interações sociais no ambiente escolar e que as experiências vivenciadas na sala de aula se desenvolvem entre os agentes que ali estão envolvidos e com isso cabe ao educador planejar e mediar o processo de ensino fazendo assim a diferença na aprendizagem dos alunos, o presente artigo insere-se nesse contexto objetivando analisar a questão multicultural no espaço escolar a fim de compreender as abordagens e perspectivas para os povos indígenas.

Para tanto foi realizada uma revisão bibliográfica do tipo sistemática integrativa sob o seguinte questionamento: de que forma a multiculturalidade é articulada no espaço escolar, com vistas às abordagens e perspectivas para os povos indígenas?

Assim, de maneira especial, buscase olhar o multiculturalismo, no espaço escolar, como universo plural, uma vez que essa pluralidade está representada por todos os agentes educacionais, ou seja, pelos discentes, docentes e demais pessoas envolvidas neste meio nos quais manifestam seus modos de ser e agir no mundo. Nesse ponto, atribui-se uma atenção especial ao agente professor, uma 
vez que a este fica o desafio de posicionarse diante dessa diversidade sem desmerecêla e para, além disso, interferir e reagir sempre que a intolerância manifestar-se em

\section{METODOLOGIA}

O presente estudo se desenvolveu por meio de uma revisão bibliográfica do tipo sistemática integrativa que adotou as seguintes etapas (detalhadas no quadro 01):

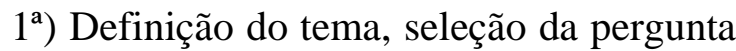
norteadora e escolha da estratégia de busca, descritores e bases de dados mais eficazes no levantamento das publicações; $2^{\mathrm{a}}$ ) Escolha dos critérios de inclusão e exclusão; $3^{a}$ ) Identificação dos estudos préselecionados e selecionados através da leitura dos agentes indexadores das publicações, como resumo, palavras-chave sua sala de aula, bem como construir práticas pedagógicas de promoção educacional, que interligue o respeito às diferenças.

e título, bem como organização dos estudos pré-selecionados e identificação dos estudos selecionados; 4 ${ }^{\mathrm{a}}$ ): Categorização dos estudos selecionados, com elaboração e uso da matriz de síntese, além de análise das informações, formação de uma biblioteca individual e avaliação crítica dos estudos selecionados; $5^{\mathrm{a}}$ ) análise, interpretação e discussão dos resultados; $6^{\mathrm{a}}$ ) Apresentação da revisão em formato de artigo, o qual contemple propostas para estudos futuros (BOTELHO; CUNHA; MACEDO, 2011; SCHMOELLER et al., 2011).Quadro 1 Detalhamento das etapas da Revisão Sistemática Integrativa.

\begin{tabular}{|c|c|c|}
\hline ETAPA & TÓPICOS DE CADA ETAPA & DETALHAMENTO DE CADA TÓPICO \\
\hline \multirow[t]{6}{*}{$1^{\mathrm{a}}$} & Tema & $\begin{array}{l}\text { A Questão Multicultural no espaço escolar: Desafios } \\
\text { para a Prática Pedagógica. }\end{array}$ \\
\hline & Pergunta norteadora & $\begin{array}{l}\text { De que forma a multiculturalidade é articulada no espaço } \\
\text { escolar, com vistas às abordagens e perspectivas para os } \\
\text { povos indígenas? }\end{array}$ \\
\hline & Objetivo geral & $\begin{array}{l}\text { Analisar a questão multicultural no espaço escolar a fim } \\
\text { de compreender as abordagens e perspectivas para os } \\
\text { povos indígenas. }\end{array}$ \\
\hline & Estratégias de busca & $\begin{array}{l}\text { Cruzamento de descritores por meio do operador boleano } \\
\text { AND; Uso de aspas nos politermos (descritor com mais } \\
\text { de um termo) para que a varredura de artigos científicos } \\
\text { contemplasse o termo exato; Uso de filtro do tipo data de } \\
\text { publicação. }\end{array}$ \\
\hline & Descritores livres e estruturados & $\begin{array}{l}\text { Multiculturalismo; Pluralidade; Diversidade; Educação } \\
\text { multicultural; Educação escolar indígena. }\end{array}$ \\
\hline & Bibliotecas Virtuais & $\begin{array}{l}\text { Scientific Electronic Library Online (SciELO); } \\
\text { Google Acadêmico; Revistas Eletrônicas. }\end{array}$ \\
\hline $2^{\mathrm{a}}$ & Período de coleta dos dados & Março a maio de 2020. \\
\hline
\end{tabular}




\begin{tabular}{|c|c|c|}
\hline & Critérios de inclusão & $\begin{array}{l}\text { Texto completo (disponível/free) do tipo: artigo original, } \\
\text { artigo de revisão, artigo na imprensa, recurso, editorial, } \\
\text { perspectiva e pesquisa transacional; Publicação (2014- } \\
\text { 2020). }\end{array}$ \\
\hline & Critérios de exclusão & $\begin{array}{l}\text { Livros, monografias, Trabalho de Conclusão de Curso, } \\
\text { Resumos, Relatórios, Teses e Dissertações; Artigos que } \\
\text { não contemplavam a relação entre a interculturalidade e } \\
\text { educação indígena. }\end{array}$ \\
\hline $3^{\mathrm{a}}$ & $\begin{array}{c}\text { Número de trabalhos } \\
\text { selecionados para revisão } \\
\text { sistemática integrativa a partir da } \\
\text { leitura dos agentes indexadores } \\
\text { das publicações (resumo, } \\
\text { palavras-chave e título) e } \\
\text { resultados, os quais deveriam } \\
\text { conter os descritores utilizados } \\
\text { nesse estudo }\end{array}$ & 24 trabalhos \\
\hline $4^{a}$ & $\begin{array}{c}\text { Categorias obtidas com a análise } \\
\text { dos trabalhos científicos } \\
\text { investigados }\end{array}$ & $\begin{array}{l}\text { - A diversidade na sala de aula: implicações para as } \\
\text { práticas pedagógicas; } \\
\text { - A educação para os povos indígenas sob a perspectiva } \\
\text { multicultural. }\end{array}$ \\
\hline $5^{\mathrm{a}}$ & $\begin{array}{l}\text { Análise, interpretação e } \\
\text { discussão dos resultados }\end{array}$ & Ver em "Resultados e Discussão" \\
\hline $6^{\mathrm{a}}$ & $\begin{array}{l}\text { Apresentação da revisão em } \\
\text { formato de artigo, o qual } \\
\text { contemple propostas para estudos } \\
\text { futuros }\end{array}$ & Esse Artigo completo \\
\hline
\end{tabular}

Fonte: elaborada pela autora.

\section{RESULTADOS E DISCUSSÃO}

Considerando os critérios de inclusão estabelecidos durante a pesquisa foram selecionados 24 artigos que contemplavam a relação entre a questão multicultural no espaço escolar e os povos indígenas, conforme descritos resumidamente no Quadro 2.

Quadro 02 - Levantamento de Publicações Científicas de Acordo com os Critérios de Inclusão.

\begin{tabular}{|c|c|c|c|c|c|}
\hline $\begin{array}{c}\mathrm{N} \\
\mathrm{o}\end{array}$ & CITAÇÃO & TEMA & $\begin{array}{c}\mathrm{AN} \\
\mathbf{O}\end{array}$ & $\begin{array}{l}\text { OBJETIVO DO } \\
\text { ESTUDO }\end{array}$ & $\begin{array}{c}\text { CONCLUSÃO DO } \\
\text { ESTUDO }\end{array}$ \\
\hline 1 & $\begin{array}{l}\text { SANTOS, R. } \\
\text { B.; SERRÂAO, } \\
\text { M. C. }\end{array}$ & $\begin{array}{l}\text { Educação escolar } \\
\text { indígena em } \\
\text { escolas urbanas: } \\
\text { realidade ou } \\
\text { utopia? }\end{array}$ & 2017 & 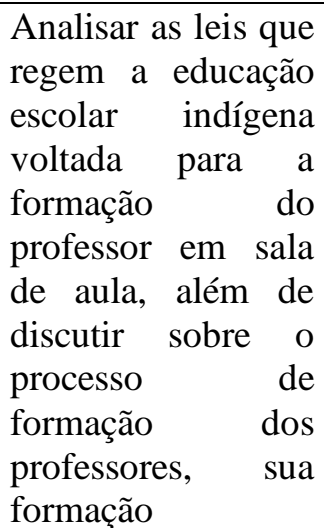 & $\begin{array}{l}\text { A partir das análises das } \\
\text { políticas educacionais } \\
\text { que regem a educação } \\
\text { escolar indígena e dos } \\
\text { dados coletados, } \\
\text { percebe-se } \\
\text { necessidade de se } \\
\text { considerar a realidade } \\
\text { educacional urbana na } \\
\text { qual os indígenas } \\
\text { encontram-se presentes } \\
\text { na formulação de }\end{array}$ \\
\hline
\end{tabular}




\begin{tabular}{|c|c|c|c|c|c|}
\hline & & & & $\begin{array}{lr}\text { continuada } & \mathrm{e} \\
\text { atuação } & \text { na } \\
\text { educação } & \text { escolar } \\
\text { indígena } & \text { no } \\
\text { município } & \text { de } \\
\text { Parintins, e } & \text { como } \\
\text { estes contribuem no } \\
\text { processo } & \text { de } \\
\text { aprendizagem } & \text { dos } \\
\text { alunos indígenas. }\end{array}$ & $\begin{array}{l}\text { políticas públicas além } \\
\text { de uma maior efetivação } \\
\text { das mesmas para que os } \\
\text { indígenas que estudam } \\
\text { em escola urbana } \\
\text { tenham formação } \\
\text { adequada } \\
\text { aprendizagem de } \\
\text { qualidade, fortalecendo } \\
\text { assim sua cultura e não } \\
\text { deixando de lado suas } \\
\text { raízes. }\end{array}$ \\
\hline 2 & $\begin{array}{c}\text { RODRIGUES, } \\
\text { W. }\end{array}$ & $\begin{array}{c}\text { O ambiente } \\
\text { escolar e a } \\
\text { valorização } \\
\text { cultural indígena. }\end{array}$ & 2016 & $\begin{array}{l}\text { Relacionar estética } \\
\text { indígena e sua } \\
\text { possível utilização } \\
\text { nas aulas escolares } \\
\text { da região, } \\
\text { incentivando } \\
\text { futuros professores } \\
\text { a se utilizarem de } \\
\text { tal concepção. }\end{array}$ & $\begin{array}{l}\text { A inclusão dos indígenas } \\
\text { no ambiente escolar (nas } \\
\text { unidades escolares } \\
\text { dentro e fora das aldeias } \\
\text { e nas universidades) } \\
\text { deve ser pautada pelo } \\
\text { respeito ao outro, pelo } \\
\text { respeito à diferença e na } \\
\text { valorização das muitas } \\
\text { contribuições que esses } \\
\text { autóctones brasileiros } \\
\text { nos forneceram e nos } \\
\text { fornecem. Assim, o } \\
\text { estudo de personagens } \\
\text { indígenas presentes na } \\
\text { literatura pode favorecer } \\
\text { o surgimento de um } \\
\text { novo olhar sobre as } \\
\text { populações indígenas } \\
\text { nacionais, a fim de } \\
\text { fortalecer on sus } \\
\text { reconhecimento de suas } \\
\text { organizações sociais, } \\
\text { suas tradições, seus } \\
\text { saberes, seus fazeres, } \\
\text { seus valores simbólicos } \\
\text { e seus processos de } \\
\text { transmissão cultural. }\end{array}$ \\
\hline 3 & $\begin{array}{l}\text { DELMONDEZ, } \\
\text { P.; PULINO, L. } \\
\text { H. C. Z. }\end{array}$ & $\begin{array}{l}\text { Sobre identidade e } \\
\text { diferença no } \\
\text { contexto da } \\
\text { educação escolar } \\
\text { indígena }\end{array}$ & 2014 & $\begin{array}{l}\text { Analisar a educação } \\
\text { escolar indígena, } \\
\text { mediante r as } \\
\text { concepções } \\
\text { identidade de } \\
\text { diferença, de } \\
\text { traçar para } \\
\text { compreensão uma } \\
\text { como as políticas } \\
\text { multiculturais de } \\
\text { educação vem } \\
\text { sendo concebidas e } \\
\text { praticadas }\end{array}$ & \begin{tabular}{lrr}
\multicolumn{3}{l}{ Historicamente, a escola } \\
afirmou a & exclusão \\
social dos & povos \\
indígenas e & hoje, & visa \\
prepará-los & para \\
relações de & negociação \\
cultural, de & constituição \\
de novas & posições \\
identitárias & e & de \\
valorização & de & sua \\
diferença. & & A \\
investigação & efetiva \\
contribuiu com o estudo
\end{tabular} \\
\hline
\end{tabular}




\begin{tabular}{|c|c|c|c|c|c|}
\hline & & & & $\begin{array}{l}\text { historicamente no } \\
\text { Brasil. }\end{array}$ & $\begin{array}{lr}\text { das } & \text { políticas } \\
\text { multiculturais } & \text { de } \\
\text { educação brasileiras } \\
\text { visando } \\
\text { desenvolvimento ao da } \\
\text { psicologia social, numa } \\
\text { perspectiva critica. }\end{array}$ \\
\hline 4 & $\begin{array}{l}\text { SOUZA, R. S.; } \\
\text { SILVA, D. G. } \\
\text { GONÇALVES, } \\
\text { T. P. N. R. }\end{array}$ & $\begin{array}{l}\text { Multiculturalismo } \\
\text { e educação: o } \\
\text { espaço da gestão. }\end{array}$ & 2019 & $\begin{array}{l}\text { Analisar } \\
\text { questões } \\
\text { interesse de } \\
\text { multiculturalismo, } \\
\text { como diferenças de } \\
\text { raça, gênero e } \\
\text { sexualidade, } \\
\text { perpassam o } \\
\text { cotidiano da gestão } \\
\text { de uma escola } \\
\text { particular } \\
\text { localizada à zona } \\
\text { oeste da cidade do } \\
\text { Rio de Janeiro. }\end{array}$ & $\begin{array}{l}\text { De forma geral, os } \\
\text { resultados apontam para } \\
\text { uma dicotomia: embora } \\
\text { as escolas teoricamente } \\
\text { se esforce em tratar } \\
\text { positivamente de } \\
\text { problemas relacionados } \\
\text { com as diferenças } \\
\text { culturais junto aos } \\
\text { discentes, foi notado que } \\
\text { parte da equipe gestora e } \\
\text { parte das (os) } \\
\text { professoras (es) parece } \\
\text { produzir estereótipos } \\
\text { relacionados ao gênero e } \\
\text { à sexualidade. }\end{array}$ \\
\hline 5 & $\begin{array}{l}\text { PEREIRA, P. F. } \\
\text { S.; NETO, J. S. }\end{array}$ & $\begin{array}{l}\text { Um pouco além } \\
\text { dos territórios: o } \\
\text { direito } \\
\text { fundamental dos } \\
\text { povos indígenas a } \\
\text { uma educação } \\
\text { diferenciada }\end{array}$ & 2017 & $\begin{array}{l}\text { Analisar } r a \\
\text { existência de um } \\
\text { direito à educação } \\
\text { diferenciada dos } \\
\text { povos indígenas, } \\
\text { sob a égide do } \\
\text { ordenamento } \\
\text { jurídico brasileiro. }\end{array}$ & $\begin{array}{l}\text { A preocupação com o } \\
\text { direito à educação } \\
\text { diferenciada dos povos } \\
\text { indígenas decorre do } \\
\text { fato de os mesmos } \\
\text { atualmente, sabedores } \\
\text { de seus direitos, tem } \\
\text { atuado nas esferas } \\
\text { discursivas formais e } \\
\text { informais apresentando } \\
\text { as suas reinvindicações, } \\
\text { o que perpassa pelo } \\
\text { respeito e garantia do } \\
\text { direito a terem um } \\
\text { processo educacional } \\
\text { que garante a diferença e } \\
\text { a pluralidade de seus } \\
\text { modos de vida. }\end{array}$ \\
\hline 6 & $\begin{array}{l}\text { SILVA, A. F. et } \\
\text { al. }\end{array}$ & $\begin{array}{l}\text { Educação } \\
\text { indígena. }\end{array}$ & 2016 & $\begin{array}{l}\text { Identificar } \\
\text { importância da } \\
\text { cultura indígena } \\
\text { para a educação e } \\
\text { refletir sobre ações } \\
\text { que contribuem } \\
\text { para o respeito à } \\
\text { diversidade cultural } \\
\text { e os direitos } \\
\text { humanos, } \\
\text { esclarecer ideias e } \\
\text { mitos }\end{array}$ & $\begin{array}{l}\text { Há uma gama de } \\
\text { oportunidades e desafios } \\
\text { para assegurar a inclusão } \\
\text { e o compromisso dos } \\
\text { estudantes indígenas } \\
\text { com os projetos sociais } \\
\text { de suas comunidades, } \\
\text { articulando tradição, } \\
\text { oralidade } \\
\text { conhecimento cientifico } \\
\text { em bases dialógicas, } \\
\text { reflexivas }\end{array}$ \\
\hline
\end{tabular}




\begin{tabular}{|c|c|c|c|c|c|}
\hline & & & & $\begin{array}{l}\text { preconceituosos ou } \\
\text { falsos a respeito do } \\
\text { povo indígena. }\end{array}$ & $\begin{array}{l}\text { propositivas. } \\
\text { conhecimento desse } \\
\text { povo agrega valor } \\
\text { histórico e político } \\
\text { frente às demandas da } \\
\text { educação, amplia } \\
\text { valores étnicos culturais, } \\
\text { criando novos caminhos } \\
\text { de inter-relações para o } \\
\text { conhecimento cientifico } \\
\text { e social. }\end{array}$ \\
\hline 7 & $\begin{array}{l}\text { FIGUEIREDO, } \\
\text { J. A. et al. }\end{array}$ & $\begin{array}{l}\text { A “inclusão" da } \\
\text { indígena na } \\
\text { escola. }\end{array}$ & 2017 & $\begin{array}{l}\text { Analisar } \\
\text { "inclusão" a } \\
\text { indígena na escola } \\
\text { "comum". }\end{array}$ & $\begin{array}{l}\text { O não conhecer da } \\
\text { cultura do outro pode } \\
\text { ocasionar } \\
\text { etnocêntrica, misão } \\
\text { vezes impedindo de } \\
\text { visualizar outas } \\
\text { possibilidades, como a } \\
\text { convivência saudável } \\
\text { entre culturas distintas. } \\
\text { Na análise feita para a } \\
\text { construção } \\
\text { trabalho; talvez a maior } \\
\text { barreira tanto do } \\
\text { convívio, como de apoio } \\
\text { ao ensino seja a língua: } \\
\text { percebendo-se como } \\
\text { fator de dificuldade na } \\
\text { permanência de alunos } \\
\text { indígenas na escola } \\
\text { 'comum'. }\end{array}$ \\
\hline 8 & $\begin{array}{l}\text { GONÇALVES, } \\
\text { J. P.; } \\
\text { OLIVEIRA, E. } \\
\text { L. }\end{array}$ & $\begin{array}{l}\text { Uma diversidade } \\
\text { cultural e relações } \\
\text { de gênero em uma } \\
\text { escola indígena } \\
\text { sul-mato- } \\
\text { grossense. }\end{array}$ & 2018 & $\begin{array}{l}\text { Investigar a opinião } \\
\text { da comunidade } \\
\text { escolar de uma } \\
\text { aldeia indígena, } \\
\text { localizada no } \\
\text { município r de } \\
\text { Tacuru (MS), } \\
\text { acerca do trabalho } \\
\text { desenvolvido por } \\
\text { professores ganero } \\
\text { indígenas do gênero } \\
\text { masculino na } \\
\text { educação infantil. }\end{array}$ & $\begin{array}{l}\text { Os dados da pesquisa } \\
\text { evidenciam que na } \\
\text { cultura indígena as } \\
\text { crianças vivem junto da } \\
\text { comunidade onde todos } \\
\text { são educadores em } \\
\text { potencial, independente } \\
\text { do gênero, de modo que } \\
\text { o cargo de professor } \\
\text { dentro de uma aldeia } \\
\text { indígena pode ser } \\
\text { considerado um cargo de } \\
\text { prestigio. Além disso, } \\
\text { para as mulheres } \\
\text { indígenas é mais difícil } \\
\text { sair da aldeia em busca } \\
\text { de uma formação, o que } \\
\text { pode explicar a } \\
\text { significativa presença } \\
\text { masculina na educação }\end{array}$ \\
\hline
\end{tabular}




\begin{tabular}{|c|c|c|c|c|c|}
\hline & & & & & $\begin{array}{l}\text { infantil na aldeia } \\
\text { indígena pesquisada. }\end{array}$ \\
\hline 9 & SANTOS, M. D & $\begin{array}{c}\text { A educação } \\
\text { indígena na pós- } \\
\text { modernidade. }\end{array}$ & 2018 & 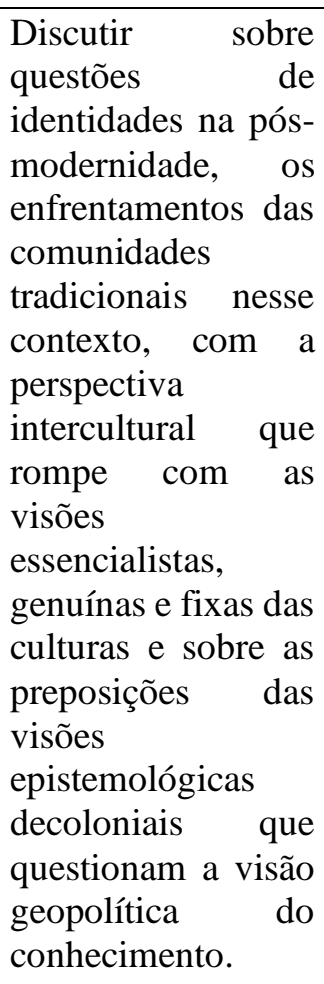 & $\begin{array}{l}\text { É na perspectiva } \\
\text { decolonial que há } \\
\text { possibilidade de pensar a } \\
\text { partir das ruinas, da } \\
\text { marginalização } \\
\text { conhecimentos, de do } \\
\text { racismo epistêmico e } \\
\text { intervir a fim de que haja } \\
\text { novas perspectivas, } \\
\text { novas pedagogias e } \\
\text { assim, contemplado os } \\
\text { etnoconhecimentos, } \\
\text { possam legitimá-los, } \\
\text { sistematiza-los e assim } \\
\text { (re)significar as } \\
\text { identidades que foram } \\
\text { subalternizadas. }\end{array}$ \\
\hline 10 & GRUBITS, S. & $\begin{array}{c}\text { Mulheres } \\
\text { indígenas } \\
\text { brasileiras: } \\
\text { educação e } \\
\text { políticas públicas }\end{array}$ & 2014 & $\begin{array}{lr}\text { Refletir até } & \text { que } \\
\text { ponto a proposta } \\
\text { formulada } & \text { pela } \\
\text { Política } & \text { Nacional } \\
\text { para as } & \text { Mulheres } \\
\text { (PNM) (Secretaria } \\
\text { Especial } & \text { de } \\
\text { Políticas para as } \\
\text { Mulheres, } 2003) \\
\text { contempla } \\
\text { grupos de mulheres } \\
\text { indígenas. }\end{array}$ & $\begin{array}{l}\text { No caso dos } \\
\text { Guarani/Kaiawá, as } \\
\text { mulheres de Dourados } \\
\text { tem uma participação } \\
\text { mais ativa dentro e fora } \\
\text { da comunidade para } \\
\text { auxiliar na renda } \\
\text { familiar, e estimulam } \\
\text { mais seus filhos para } \\
\text { estudar e chegar até a } \\
\text { universidade. Entre os } \\
\text { Kadiwéu, o fato mais } \\
\text { relevante é a questão do } \\
\text { poder político das } \\
\text { mulheres e uma divisão } \\
\text { de papeis entre homens e } \\
\text { mulheres, sem que seja } \\
\text { atribuído mais valor a } \\
\text { um papel do que a outro. } \\
\text { No estudo com os } \\
\text { Terena, observamos que } \\
\text { a relação próxima com a } \\
\text { sociedade nacional vem } \\
\text { propiciando muitas } \\
\text { transformações e uma } \\
\text { atuação cada vez maior }\end{array}$ \\
\hline
\end{tabular}




\begin{tabular}{|c|c|c|c|c|c|}
\hline & & & & & $\begin{array}{l}\text { da mulher dentro e fora } \\
\text { da comunidade. }\end{array}$ \\
\hline 11 & $\begin{array}{l}\text { FREITAS DE } \\
\text { LIMA, E. }\end{array}$ & $\begin{array}{l}\text { A construção de } \\
\text { práticas } \\
\text { pedagógicas } \\
\text { inter/multiculturai } \\
\text { s no ensino } \\
\text { fundamental e os } \\
\text { saberes docentes. }\end{array}$ & 2014 & $\begin{array}{l}\text { Problematizar } \\
\text { construção } \\
\text { práticas } \\
\text { pedagógicas } \\
\text { inter/multiculturais } \\
\text { no Ensino } \\
\text { Fundamental, em } \\
\text { contraponto com a } \\
\text { concepção de } \\
\text { saberes docentes. }\end{array}$ & $\begin{array}{l}\text { Para desenvolver os } \\
\text { conteúdos escolares } \\
\text { inter/multiculturalmente } \\
\text {, não basta que o docente } \\
\text { construa e acione } \\
\text { saberes, entendidos na } \\
\text { perspectiva racional; é } \\
\text { preciso que tais saberes } \\
\text { sejam conjugados com } \\
\text { crenças e valores } \\
\text { coerentes com esse tipo } \\
\text { de atuação, o que requer } \\
\text { uma autopercepção mais } \\
\text { honesta por parte dos } \\
\text { professores. }\end{array}$ \\
\hline 12 & $\begin{array}{l}\text { GALVÃO, C. } \\
\text { M. P.; } \\
\text { LACERDA, M. } \\
\text { C. }\end{array}$ & $\begin{array}{l}\text { Multiculturalismo } \\
\text { em educação }\end{array}$ & 2018 & $\begin{array}{l}\text { Abordar o que é } \\
\text { multiculturalismo, } \\
\text { onde surgiu, como } \\
\text { se processa e } \\
\text { desafios para a } \\
\text { superação dos } \\
\text { impasses gerados } \\
\text { por essa pluralidade } \\
\text { cultural. }\end{array}$ & $\begin{array}{l}\text { Defendemos } \\
\text { multiculturalismo } \\
\text { crítico para quem as } \\
\text { diferenças não tem um } \\
\text { fim em si, mas situam-se } \\
\text { num contexto de lutas } \\
\text { por mudança social, } \\
\text { contrapondo-se ao } \\
\text { ideário neoliberal e a } \\
\text { globalização econômica } \\
\text { e cultural vigente, como } \\
\text { expressões legítimas do } \\
\text { modelo capitalista } \\
\text { opressor. Contudo, } \\
\text { somos a favor do } \\
\text { multiculturalismo } \\
\text { crítico, entendendo que } \\
\text { o respeito à vida } \\
\text { humana, diversidade } \\
\text { cultural e essencial para } \\
\text { a construção de um } \\
\text { mundo de paz, como } \\
\text { futuro educador vemos } \\
\text { na instituição escolar } \\
\text { uma força maior que nos } \\
\text { conduzirá a esse } \\
\text { processo de justiça } \\
\text { social e democracia. }\end{array}$ \\
\hline 13 & $\begin{array}{l}\text { CILIATO, F. } \\
\text { G.; SARTORI, } \\
\text { J. }\end{array}$ & $\begin{array}{l}\text { Pluralidade } \\
\text { cultural: os } \\
\text { desafios aos } \\
\text { professores em } \\
\text { frente da } \\
\text { diversidade } \\
\text { cultural }\end{array}$ & 2015 & $\begin{array}{l}\text { Abordar } r \\
\text { importância de } \\
\text { trabalhar na escola } \\
\text { com os temas } \\
\text { transversais, de } \\
\text { modo que contribua } \\
\text { para a formação de }\end{array}$ & $\begin{array}{l}\text { Levando } \\
\text { consideração a análise } \\
\text { do trabalho e do } \\
\text { contexto } \\
\text { notamos que os alunos } \\
\text { demonstram interesse } \\
\text { pelos assuntos e que }\end{array}$ \\
\hline
\end{tabular}




\begin{tabular}{|c|c|c|c|c|c|}
\hline & & & & $\begin{array}{l}\text { um cidadão ético e } \\
\text { responsável, } \\
\text { sobretudo, em } \\
\text { relação } \\
\text { pluralidade } \\
\text { cultural. }\end{array}$ & 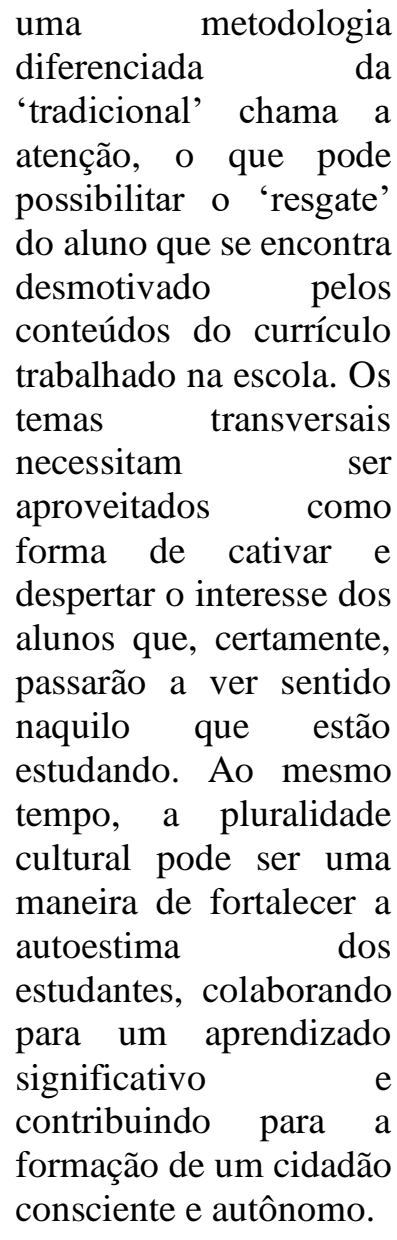 \\
\hline 14 & $\begin{array}{l}\text { KAYAPÓ, E.; } \\
\text { BRITO, T. }\end{array}$ & $\begin{array}{l}\text { A pluralidade } \\
\text { étnico-cultural } \\
\text { indígena no } \\
\text { Brasil: o que a } \\
\text { escola tem a ver } \\
\text { com isso? }\end{array}$ & 2014 & $\begin{array}{lr}\text { Analisar } & \text { as } \\
\text { possibilidades de } \\
\text { inovação no estudo } \\
\text { da história e cultura } \\
\text { indígena nas } \\
\text { escolas brasileira, } \\
\text { buscando romper } \\
\text { com r o } \\
\text { silenciamento e os } \\
\text { preconceitos } \\
\text { produzidos pelo } \\
\text { Estado, pela } \\
\text { sociedade e pela } \\
\text { escola ao longo do } \\
\text { tempo. }\end{array}$ & $\begin{array}{l}\text { Os esforços para a } \\
\text { promoção da Lei } \\
11.645 / 08, \text { no que tange } \\
\text { ao estudo da história e } \\
\text { cultura indígena esbarra } \\
\text { em limites complexos, } \\
\text { entre eles, a morosidade } \\
\text { e o reduzido interesse } \\
\text { das escolas e poder para } \\
\text { promover cursos de } \\
\text { formação dos } \\
\text { professores e produção } \\
\text { de material didático } \\
\text { específico sobre a } \\
\text { temática. }\end{array}$ \\
\hline 15 & $\begin{array}{l}\text { MONTEIRO, F. } \\
\text { M. A.; } \\
\text { FONTOURA, } \\
\text { H. A.; CANEN, } \\
\text { A. }\end{array}$ & $\begin{array}{l}\text { Ressignificando } \\
\text { práticas de ensino } \\
\text { e de formação } \\
\text { docente: } \\
\text { contribuições de } \\
\text { narrativas, } \\
\text { diálogos e } \\
\text { conferências. }\end{array}$ & 2014 & $\begin{array}{l}\text { Apresentar } \\
\text { contribuições } \\
\text { compartilhadas } \\
\text { sobre dimensões } \\
\text { vinculadas às } \\
\text { práticas de } \\
\text { formação docente e } \\
\text { de pesquisa } \\
\text { desenvolvidas em } \\
\text { contextos diversos, }\end{array}$ & $\begin{array}{l}\text { Destacam-se } \\
\text { contribuições para os } \\
\text { desafios atuais da } \\
\text { educação. } \\
\text { especificamente, chama- } \\
\text { se a atenção para as } \\
\text { formas pelas quais tais } \\
\text { experiencias incorporam } \\
\text { sensibilidades às } \\
\text { diversidades culturais, }\end{array}$ \\
\hline
\end{tabular}




\begin{tabular}{|c|c|c|c|c|c|}
\hline & & & & $\begin{array}{l}\text { com interlocução } \\
\text { entre metodologias } \\
\text { e dados plurais. }\end{array}$ & $\begin{array}{l}\text { buscando caminhos } \\
\text { viabilizadores à } \\
\text { recontextualização das } \\
\text { estratégias e práticas } \\
\text { formativas docentes, em } \\
\text { prol de transformações } \\
\text { que incorporem } \\
\text { sensibilidades } \\
\text { multiculturais em seu } \\
\text { desenvolvimento. }\end{array}$ \\
\hline 16 & $\begin{array}{l}\text { ARAÚJO, N. } \\
\text { B.; MOTA, C. } \\
\text { M. A. }\end{array}$ & $\begin{array}{l}\text { Profissionalidades } \\
\text { e práticas docentes } \\
\text { multiculturais: } \\
\text { lugares possíveis? }\end{array}$ & 2017 & $\begin{array}{l}\text { Favorecer reflexões } \\
\text { acerca da inserção } \\
\text { da diversidade } \\
\text { cultural nas práticas } \\
\text { de sala de aula, } \\
\text { tomando-a sob um } \\
\text { enfoque } \\
\text { multicultural, } \\
\text { potencializador de } \\
\text { abordagens } \\
\text { educativas que se } \\
\text { centrem nas } \\
\text { discussões } \\
\text { demandas } \\
\text { realidade atual. }\end{array}$ & $\begin{array}{l}\text { Um fazer docente que } \\
\text { olha para a } \\
\text { multiculturalidade, } \\
\text { precisa estar muito bem } \\
\text { ancorado numa } \\
\text { abordagem para além do } \\
\text { reconhecimento da } \\
\text { diversidade, mas } \\
\text { tomando-a como } \\
\text { elemento que engendra } \\
\text { inúmeras questões } \\
\text { históricas, sociais e } \\
\text { culturais que precisam } \\
\text { ser revisitadas e, em } \\
\text { muitos casos, } \\
\text { descontruídas. Logo, as } \\
\text { abordagens não devem } \\
\text { prender-se a } \\
\text { superficialidades para } \\
\text { não corrermos o risco de } \\
\text { folclorizar, ao invés de } \\
\text { reconhecer para o } \\
\text { fortalecimento. }\end{array}$ \\
\hline 17 & $\begin{array}{l}\text { BAVARESCO, } \\
\text { P. R.; TACCA, } \\
\text { D. P. }\end{array}$ & $\begin{array}{l}\text { Multiculturalismo } \\
\text { e diversidade } \\
\text { cultural: uma } \\
\text { reflexão }\end{array}$ & 2016 & 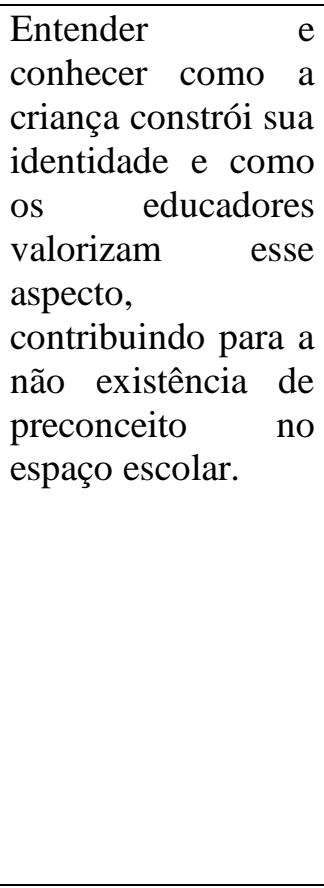 & $\begin{array}{l}\text { Uma escola considerada } \\
\text { multicultural, para ser de } \\
\text { qualidade deve, então, } \\
\text { ser inclusiva e deve } \\
\text { também apostar em um } \\
\text { sistema educativo } \\
\text { centrado no } \\
\text { relacionamento, na } \\
\text { igualdade, e que as } \\
\text { atividades estejam } \\
\text { voltadas para a } \\
\text { diversidade presente na } \\
\text { sala de aula. A ação do } \\
\text { professor deve ser um } \\
\text { ato intencional na sua } \\
\text { prática pedagógica; deve } \\
\text { reconhecer as diferenças } \\
\text { culturais e saber } \\
\text { valorizar o potencial da } \\
\text { diversidade de cada um. }\end{array}$ \\
\hline
\end{tabular}




\begin{tabular}{|c|c|c|c|c|c|}
\hline 18 & SILVA, J. B. & $\begin{array}{c}\text { Formação, } \\
\text { pesquisa e práticas } \\
\text { no contexto da } \\
\text { educação escolar } \\
\text { indígena: as ações } \\
\text { do PIBID } \\
\text { diversidade no } \\
\text { povo Xukuru do } \\
\text { Ororubá }\end{array}$ & 2017 & $\begin{array}{l}\text { Identificar o } \\
\text { trabalho realizado } \\
\text { nas escolas do povo } \\
\text { Xukuru. }\end{array}$ & 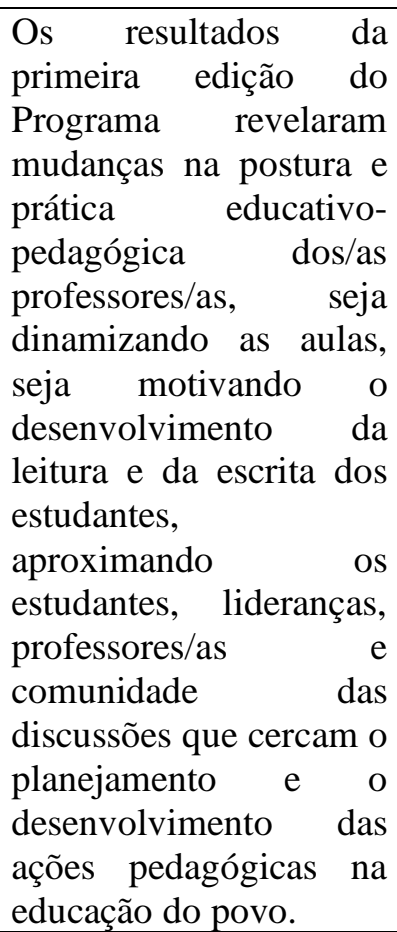 \\
\hline 19 & $\begin{array}{l}\text { ABU-EL-HAY, } \\
\text { M. F.; FIALHO, } \\
\text { L. M. F. }\end{array}$ & $\begin{array}{c}\text { Formação docente } \\
\text { e práticas } \\
\text { pedagógicas } \\
\text { multiculturais } \\
\text { críticas. }\end{array}$ & 2019 & $\begin{array}{l}\text { Compreender como } \\
\text { se constituiu a } \\
\text { formação docente } \\
\text { de professoras da } \\
\text { educação básica } \\
\text { estadunidense para } \\
\text { o desenvolvimento } \\
\text { de posturas e } \\
\text { práticas } \\
\text { multiculturais no } \\
\text { ambiente escolar. }\end{array}$ & $\begin{array}{l}\text { As histórias de vida das } \\
\text { professoras foram } \\
\text { marcadas por vivencias } \\
\text { em situações de conflito } \\
\text { social e experiências de } \\
\text { exclusão cultural e } \\
\text { educacional, } \\
\text { especialmente em } \\
\text { relação à diversidade } \\
\text { étnico-racial. Essas } \\
\text { vivencias foram } \\
\text { determinantes para a } \\
\text { busca da formação e } \\
\text { atuação profissional } \\
\text { docente dentro de uma } \\
\text { concepção de educação } \\
\text { multicultural. } \\
\text { formação } \\
\text { perspectiva se mostrou } \\
\text { relevante para a adoção } \\
\text { de práticas educativas } \\
\text { inclusivas, no entanto, } \\
\text { foram as experiencias de } \\
\text { exclusão que motivaram } \\
\text { o compromisso das } \\
\text { professoras com a } \\
\text { educação multicultural } \\
\text { crítica. }\end{array}$ \\
\hline 20 & $\begin{array}{c}\text { LISBOA } \\
\text { GROSS, D. G. } \\
\text { et al. }\end{array}$ & $\begin{array}{l}\text { Reflexões acerca } \\
\text { da etnicidade e } \\
\text { diversidade } \\
\text { cultural na BNCC } \\
\text { e no PNE }\end{array}$ & 2019 & $\begin{array}{l}\text { Apontar quais as } \\
\text { estratégias, metas } \\
\text { do PNE e as } \\
\text { competências da } \\
\text { BNCC acerca da }\end{array}$ & $\begin{array}{l}\text { Seria melhor que ambos } \\
\text { documentos atendessem } \\
\text { às políticas educacionais } \\
\text { e que se levasse em } \\
\text { consideração sempre a }\end{array}$ \\
\hline
\end{tabular}




\begin{tabular}{|c|c|c|c|c|c|}
\hline & & & & $\begin{array}{l}\text { etnicidade } \\
\text { diversidade } \\
\text { cultural. }\end{array}$ & $\begin{array}{l}\text { multiplicidade } \\
\text { realidades das escolas, } \\
\text { infraestruturas, culturas, } \\
\text { formações profissionais } \\
\text { e o aluno, respeitando a } \\
\text { peculiaridade e a } \\
\text { singularidade de cada } \\
\text { cenário, envolvendo } \\
\text { assim a correta } \\
\text { compreensão ra } \\
\text { etnicidade e diversidade } \\
\text { cultural. }\end{array}$ \\
\hline 21 & $\begin{array}{l}\text { DOMINGUES, } \\
\text { M. P. B.; } \\
\text { COTA, F. S. }\end{array}$ & $\begin{array}{l}\text { A diferença na } \\
\text { sala de aula: } \\
\text { reflexões sobre a } \\
\text { história indígena } \\
\text { escolar e a história } \\
\text { de educação } \\
\text { inclusiva }\end{array}$ & 2014 & $\begin{array}{l}\text { Trazer reflexões } \\
\text { sobre o ensino da } \\
\text { história indígena } \\
\text { escolar e sobre a } \\
\text { história r da } \\
\text { educação inclusiva, } \\
\text { no sentido de } \\
\text { promover um } \\
\text { diálogo crítico entre } \\
\text { a multiplicidade de } \\
\text { sujeitos, tempos, } \\
\text { lugares e culturas. }\end{array}$ & $\begin{array}{l}\text { Repensar e ressignificar } \\
\text { a concepção de educador } \\
\text { deve ser uma prática, e } \\
\text { através desta propor } \\
\text { estímulos que ativem as } \\
\text { diferenças entre os } \\
\text { sujeitos em seu contexto } \\
\text { histórico, cultural e } \\
\text { social e na elaboração de } \\
\text { sentidos. Formandos } \\
\text { sujeitos da melhor } \\
\text { forma, para viver a vida } \\
\text { em sua plenitude, } \\
\text { atendendo as suas } \\
\text { especificidades } \\
\text { respondendo e } \\
\text { necessidades de cada } \\
\text { um. }\end{array}$ \\
\hline 22 & $\begin{array}{l}\text { COUTINHO, } \\
\text { C.; } \\
\text { RUPPENTHAL } \\
\text {. R. }\end{array}$ & $\begin{array}{c}\text { Cultura e } \\
\text { educação } \\
\text { científica: } \\
\text { alternativas } \\
\text { pedagógicas para } \\
\text { inserção do } \\
\text { multiculturalismo } \\
\text { na formação } \\
\text { inicial de } \\
\text { professores. }\end{array}$ & 2016 & $\begin{array}{lr}\text { Trazer à } & \text { tona } \\
\text { reflexões referentes } \\
\text { à multicultura } & \text { na } \\
\text { educação, r em } \\
\text { especial r na } \\
\text { educação científica. }\end{array}$ & $\begin{array}{l}\text { Pode-se destacar a } \\
\text { presença dos aspectos } \\
\text { referentes a } \\
\text { multiculturalidade desde } \\
\text { a elaboração dos PCN } \\
\text { em 1997, bem como em } \\
\text { outros documentos. } \\
\text { Entretanto, ainda faltam } \\
\text { trabalhos ou pesquisas } \\
\text { que contribuam no } \\
\text { sentido de oferecer } \\
\text { subsídios para que } \\
\text { práticas multiculturais } \\
\text { se façam presente nas } \\
\text { escolas, direcionadas } \\
\text { aos estudantes ou aos } \\
\text { professores, em } \\
\text { formação ou que já estão } \\
\text { na atividade. }\end{array}$ \\
\hline 23 & $\begin{array}{l}\text { NAZZARENO, } \\
\text { E.; ARAÚJO, } \\
\text { O. C. G. }\end{array}$ & $\begin{array}{l}\text { Reflexões em } \\
\text { torno do tema } \\
\text { contextual } \\
\text { "etnicidade e }\end{array}$ & 2017 & $\begin{array}{l}\text { Apresentar } \quad \text { o } \\
\text { desenvolvimento } \\
\text { do tema contextual } \\
\text { "etnicidade } \\
\text { diversidade }\end{array}$ & $\begin{array}{lr}\mathrm{Na} \text { condição } & \text { de } \\
\text { professores, } & \text { os } \\
\text { estudantes afirmaram } \\
\text { estar cientes do que é } \\
\text { fundamental } & \text { que }\end{array}$ \\
\hline
\end{tabular}




\begin{tabular}{|c|c|c|c|c|c|}
\hline & & $\begin{array}{l}\text { diversidade } \\
\text { cultural" }\end{array}$ & & \begin{tabular}{lr}
\multicolumn{3}{c}{ cultural" ministrado } \\
no curso de \\
Licenciatura em \\
Educação \\
Intercultural da \\
Universidade \\
Federal de Goiás.
\end{tabular} & $\begin{array}{l}\text { estejam preparados para } \\
\text { atuar na escola a fim de } \\
\text { assegurar a revitalização } \\
\text { da lingua materna e da } \\
\text { cultura de cada povo por } \\
\text { meio da escola bilingue } \\
\text { intercultural. Mais do } \\
\text { que isto, houve a } \\
\text { compreensão de que é } \\
\text { necessário continuar a } \\
\text { luta pela permanência do } \\
\text { reconhecimento e do } \\
\text { respeito pela diversidade } \\
\text { cultural brasileira bem } \\
\text { como da garantia dos } \\
\text { direitos constitucionais } \\
\text { indígenas obtidos na } \\
\text { constituicão de } 1988 \text {. }\end{array}$ \\
\hline 24 & $\begin{array}{c}\text { FERRÃO } \\
\text { CANDAU, V. } \\
\text { M. }\end{array}$ & $\begin{array}{l}\text { Ser professor/a } \\
\text { hoje: novos } \\
\text { confrontos entre } \\
\text { saberes, culturas e } \\
\text { práticas. }\end{array}$ & 2014 & \begin{tabular}{lr} 
Analisar & \multicolumn{2}{c}{ alguns } \\
desafios que & os \\
professores e & o \\
trabalho docente \\
estão chamados a \\
enfrentar & na \\
perspectiva & da \\
exigência & de \\
ressignificação & da \\
escola & na \\
contemporaneidade \\
.
\end{tabular} & $\begin{array}{lr}\text { Conceber o } & \text { educador } \\
\text { como um } & \text { agente } \\
\text { sociocultural } & \text { ainda } \\
\text { constitui r } & \text { uma } \\
\text { perspectiva } & \text { somente } \\
\text { anunciada em } & \text { alguns } \\
\text { cursos de formação } \\
\text { inicial e/ou continuada } \\
\text { de educadores. No } \\
\text { entanto, consideramos } \\
\text { que esta perspectiva é } \\
\text { fundamental re } \\
\text { queremos contribuir } \\
\text { para que a escola seja } \\
\text { reinventada e se afirme } \\
\text { como um lócus } \\
\text { privilegiado ro de } \\
\text { formação de novas } \\
\text { identidades rades } \\
\text { mentalidades capazes de } \\
\text { construir respostas, } \\
\text { sempre com caráter } \\
\text { histórico e provisório, } \\
\text { para as grandes questões } \\
\text { que enfrentamos na } \\
\text { atualidade. }\end{array}$ \\
\hline
\end{tabular}

Fonte: elaborado pela autora.

\section{A Diversidade na Sala de Aula: Implicações para as Práticas Pedagógicas}

O Brasil possui uma constituição que lhe confere a condição de nação pluriétnica. Entretanto, durante décadas tal diversidade cultural brasileira não foi reconhecida equanimemente pela escola. Como reflexo do processo histórico, observou-se no ambiente escolar "o predomínio, para não dizer hegemonia, da 
matriz cultural europeia como cultura eleita para o trabalho pedagógico. Porém, a atual discussão sobre as conjunturas sociais tem promovido aberturas de espaços para maior número de contestações e revoltas dos diversos setores excluídos" (Gonçalves, 2012, apud Michaliszyn, 2014, p. 105).

É possível perceber que há certo abismo entre a cultura escolar e a cultura de referência dos alunos, principalmente se estes pertencerem a grupos sociais, étnicas e culturas marginalizados. No entanto, não se pode discordar que a educação é fundamental na construção e na valorização de um mundo verdadeiramente plural. Assim, quando a escola adota modelos tradicionais, supervalorizando a cultura determinada pela minoria que detém o controle social, assume uma posição manipuladora e massificadora (CANDAU, 2014).

Para Moser (2017), esse cenário exige dos profissionais da educação constantes reflexões acerca das relações entre cultura e educação. Os critérios de avaliação devem ser concebidos considerando a perspectiva da diversidade e do multiculturalismo. Além disso, o professor deve respeitar as noções de dignidade humana e a justiça, pois não há homogeneidade cultural, cada sujeito atribui diferentes sentidos e significados sociais.
De acordo com Domingues; Cota (2014, p. 12), “aos professores é designado um grande desafio: superar uma tradição que pretende instituir e dar legitimidade a identidades sociais únicas e hegemônicas, apagando diferenças". Desse modo é importante que o professor considere cada aluno como um sujeito portador de características socioculturais próprias e, portanto, resultantes de suas vivências, sempre considerando que em sua inserção como ator social no universo da cultura, cada sujeito constrói-se a partir do momento em que é estimulado a apropriar-se, a criar e a recriar os elementos culturais a que têm acesso, num diálogo constante com os componentes da estrutura social e com as contradições nela presentes (CANDAU, 2014).

A educação e a cultura da diversidade trabalham para tornar a sociedade cooperativa e solidária, calcada no respeito pela diferença e pelos direitos humanos, tornando os homens e as mulheres justos e livres. Aqui, a escola tem um papel fundamental: é ela o agente de transformação social. A escola, e todos os espaços em que a educação acontece, compreende as diferenças dos alunos com um grande valor e não como elemento de segregação por isso a tolerância é essencial (CANDAU, 2014). 
O processo educativo compreende o oferecimento de instrumentos e alternativas para que os indivíduos tomem consciência de si, do outro e, de modo geral, da sociedade na qual vivem. Para tanto, sugere-se, como estratégia para eliminar posturas etnocêntricas, a adoção do relativismo cultural como norteador ético. Isso "implica em tornar acessível aos alunos o conhecimento sobre as diferentes sociedades e atores sociais, descontruir discursos discriminatórios e dar aos estudantes uma compreensão de que somos constituídos como sujeitos na diversidade de experiências históricas com o 'outro"” (DOMINGUES; COTA, 2014, p. 12).

No que diz respeito ao ambiente na sala de aula, é preciso que o professor tenha em mente um processo educativo que valoriza e se preocupa com a diversidade que deve ser marcado pelo ato de ponderar sobre as relações sociais estabelecidas na escola e pela constante reflexão sobre as diferenças, a desigualdade social e suas consequências. Nesse sentido, Bavaresco; Tacca (2016, p. 66) ressaltam que, "os educadores precisam considerar os princípios de uma educação inclusiva valorizando a diversidade humana, a celebração das diferenças, o direito de sentir-se parte, de pertencer, a igualdade de todos e o desenvolvimento de todas as crianças no ensino regular, na busca de uma escola para todos".

É nesse contexto que se destaca a educação multicultural onde "o entendimento do multiculturalismo como princípio educativo, deve favorecer aprendizagens que olhem para os valores sociais e culturais do outro, não de forma hierárquica, mas dialógica e relacional, partindo da realidade constituinte do espaço escolar" (ARAÚJO; MOTA, 2017, p. 70).

Assim, pensar o processo de ensino e aprendizagem numa perspectiva multicultural não significa promover festas, trabalhar com manifestações folclóricas, lendas e mitos.

Para além disso - ou melhor, em paralelo a todas essas ações, que tampouco devem ser descartadas -, devemos ter sempre em mente que lidamos com realidade distintas e culturas diversificadas (ARAÚJO; MOTA, 2017).

Para além das mudanças curriculares, é necessário o desenvolvimento de ações que ampliem as possibilidades de implementação de atividades e projetos que possam sugerir o envolvimento dos alunos com os diferentes grupos culturais, onde a relação teoria/prática no que se refere à diversidade cultural é favorecida (ARAÚJO; MOTA, 2017) 
Araújo; Mota (2017, p. 81) sinalizam que "um fazer docente que olha para a multiculturalidade, precisa estar muito bem ancorado numa abordagem para além do reconhecimento da diversidade, mas tomando-a como elemento que engendra inúmeras questões históricas, sociais e culturais que precisam ser revisitadas e, em muitos casos, desconstruídas".

Assim, considerando que as diversas formas de expressões e grupos culturais invadem a sala de aula, compreende-se que por esse motivo a escola não pode ser pensada apenas por um determinado grupo social. A diversidade deve fazer parte da escola, através da gestão democrática, garantindo a participação de todos na construção dos espaços de ensino e aprendizagem. Fica evidente que respeitar a diversidade não se refere somente a incluir diferentes grupos no mesmo espaço, mas se refere à participação de todos nesse espaço (MOSER, 2017).

Bavaresco; Tacca (2016, p. 65), afirmam que "a diversidade humana presente na escola traz constantes discussões acerca de como os professores devem, em sua prática pedagógica diária, abranger a quantidade inesgotável de diferenças que compõem o meio escolar". Por isso, é importante que os professores administrem a heterogeneidade presente em seu grupo de alunos, ampliando os processos de gestão da turma, fortalecendo uma relação de apoio em especial àqueles alunos que mais precisam de atenção para superar suas dificuldades, bem como fomentando uma relação de apoio e incentivo entre os alunos. Dessa forma "a ação do professor deve ser um ato intencional na sua prática pedagógica; deve reconhecer as diferenças culturais e saber valorizar o potencial da diversidade de cada um" (BAVARESCO; TACCA, 2016, p. $67)$.

Essa nova realidade educacional solicita que o processo educativo seja repensado e que se busquem novos caminhos para construção de conhecimentos que poderão inovar a prática pedagógica. Coutinho; Ruppenthal (2016, p. 46) ressaltam que "para as práticas multiculturais chegarem até a escola, é importante que os professores tenham algum preparo na implementação de atividades que considerem as diferentes culturas". Nesse sentido, destaca-se "a necessidade de uma formação docente que traga presente os fundamentos sobre $\mathrm{o}$ multiculturalismo em que seja oportunizado um trabalho articulado entre teoria e prática que ofereça mecanismos para $o$ desenvolvimento de práticas pedagógicas pautadas nas questões da cultura local [...]" (ARAÚJO; MOTA, 2017, p. 73). 
É possível encontrar na literatura diversos estudos sobre a formação e a prática docente que abordam o conhecimento, o saber docente e sua formação enfocando a necessidade de buscar e repensar alternativas que possam contribuir para mudanças na prática profissional do professor, partindo de outra forma de entender, de praticar e de organizar o trabalho. Para Araújo; Mota (2017, p. 71), “a Formação docente é mecanismo de grande relevância para a construção de novas concepções educacionais que possam estar embasadas nos princípios de ressignificação a partir da superação de proletarização da profissão e busca pela autonomia que a mesma requer".

Os estudos apontados na literatura têm apresentado uma nova epistemologia da prática profissional e apontam para a melhoria da qualidade na formação docente, de forma a atender aos desafios da sociedade contemporânea. As práticas educativas, na perspectiva multicultural, tornaram-se o foco das discussões entre legisladores e educadores, com o intuito de melhorar a orientação dos professores no que se refere ao processo de ensinoaprendizagem que valorize a diversidade na sala de aula. Araújo; Mota (2017, p. 75), esclarecem que "o processo de trabalho com e para a diversidade precisa estar muito bem alicerçado pelo binômio teoria e prática, uma vez que não dá para pensar em um fazer educativo, sem estar centrado nas questões de seu tempo, sem o estabelecimento de uma postura analíticoreflexiva por parte daqueles que constituem elemento central de todo esse processo: o docente".

Abu-El-Haj; Fialho (2019, p. 23) afirmam que, "essa constatação reconhece o valor da formação acadêmica multicultural na prática pedagógica do professor" tendo em vista que, no momento em que o profissional observa as questões do seu cotidiano e as coloca como situações problemáticas, isso o levará à reflexão, então, uma reflexão na própria ação. Isso permitirá a ele reorientar sua ação a respeito da situação que vivencia. Entende-se com isso, que o professor precisa ser capaz de agir de forma a garantir um movimento de ação-reflexão-ação, e isso ocorrerá quando esse profissional fizer uma leitura de sua prática, seus conceitos e suas posturas, tornando-se assim um profissional reflexivo.

Quando o professor não assume essa postura, ele não avalia sua atuação, não reflete sobre seu cotidiano e, dessa forma, não tem condições de recriar as teorias, deixando de adequar sua prática de acordo com a realidade.

Segundo Araújo; Mota (2017, p. 81) "romper com práticas escolares 
cristalizadas não é uma tarefa simples e fácil, principalmente porque estas estão muito bem alicerçadas em antigos entornos formativos e sociais de uma parcela bastante significativa dos docentes que ora desenvolvem tais práticas". Assim, a postura do professor enquanto pesquisador é fundamental para a realização de uma autoavaliação e reformulação de sua prática. "Destarte, a dimensão formativa docente, enquanto lugar da profissionalidade que tem a prática norteada pela criticidade e autonomia, mostra-se como elemento fundamental para $\mathrm{o}$ favorecimento de reflexões que venham repercutir em práticas que, de fato, potencializem as diferenças".

Diante disso, entende-se que a formação multicultural deverá apresentar para os docentes um conjunto de estratégias baseadas em programas curriculares que expressem a diversidade de culturas e estilos de vida, tendo em vista a promoção da mudança de percepções e atitudes que facilitem a compreensão e a tolerância entre indivíduos de origens étnicas diversas. Tais estratégias deverão promover a igualdade e a eliminação da discriminação, de preconceitos existentes na sociedade. Isso é fundamental para dar voz aos alunos, fazendo que eles tenham um papel ativo na escola e na sociedade à qual pertencem.

\section{A Educação para os Povos Indígenas sob a Perspectiva Multicultural}

\section{A Educação Indígena é} caracterizada pela metodologia habitual de aquisição de conhecimentos e costumes intrínsecos de cada etnia. Sobrinho, Souza e Bettiol (2017, p. 59) afirmam que "estes saberes/conhecimentos são ensinados/aprendidos de forma oral no dia a dia, nos rituais, nos mitos e nas distintas formas de organização de cada comunidade". Como se sabe o contato entre os colonizadores e os povos colonizados iniciou um processo de aculturação que marcou a história da sociedade brasileira, onde os povos indígenas e africanos foram brutalmente escravizados visando $\mathrm{o}$ progresso e a riqueza dos colonizadores.

Para Lima et al (2017, p. 45) “A história brasileira mostra que a relação entre o Estado e os povos indígenas foi pautada pela dominação, por meio da integração e homogeneização cultural, ao invés do pluralismo cultural". Assim, esses procedimentos, que envolviam a escravização dos povos indígenas, bem como as iniciativas de catequizá-los e domesticá-los, aumentou consideravelmente as desigualdades sociais vivenciadas por esse grupo étnico até os momentos atuais.

No que se refere à história da educação escolar indígena, o que se sabe é 
que desde o início da colonização até a promulgação da Constituição Federal (CF) de 1988, os programas educacionais fundamentaram-se na desvalorização e abandono das referências culturais e práticas sociais indígenas, objetivando assim incorporar os valores e significados europeus (AFONSO, 2016).

Nesse sentido Silva e Freitas (2014, p. 10) afirmam que "todas as iniciativas educativas implementadas por meio das políticas indigenistas anteriores à Constituição Federal de 1988, tinham como o propósito de realizar um trabalho pedagógico na perspectiva de abolir com as especificidades étnicas e culturais e por meio da negação a sociodiversidade do Brasil".

Embora os colonizadores tenham tentado integrar os povos indígenas à sociedade brasileira através de uma educação assimilacionista, excluindo as culturas e valores indígenas, o que se percebeu é que tal modelo educacional "não conseguiu efetivamente desconstruir suas identidades e seus sentimentos de pertencimento a um povo que não queria perder suas origens e referências identitárias"

Desse modo, os povos indígenas brasileiros lutaram para manter viva as culturas, "mostrando que em suas comunidades é presente a coexistência de costumes ancestrais com traços culturais recentes" (PESSOA, 2017, p. 210).

A partir da promulgação da Constituição de 1988 quando "novas políticas culturais são definidas e novos grupos sociais ganham visibilidade no campo histórico-cultural e patrimonial" (VOLKMER et al., 2015, p. 53), vários povos indígenas perceberam que a educação escolar seria um meio de reduzir a desigualdade existente, e com isso estabeleceriam seus direitos e suas conquistas, além de promover um “diálogo intercultural entre diferentes agentes sociais" (SOBRINHO, SOUZA E BETTIOL, 2017, p. 59).

Desse modo, Nessa luta pelo reconhecimento da sociedade, os indígenas brasileiros no século XX, tendo a orientação e o apoio de vários representantes dos movimentos sociais, além de lutar pelo direito às suas terras, empreenderam também uma luta pelo direito à uma Educação Escolar Indígena, onde suas culturas e seus saberes fossem fortalecidos e valorizados (PESSOA, 2017).

Com isso, observa-se que nas últimas décadas, através dos movimentos de afirmação étnica, um novo modelo escolar surgiu no cenário educacional brasileiro: a escola dos e para os povos indígenas, protegida por leis que determinaram um paradigma individualizado e específico de 
educação escolar, onde as ações destinadas à educação escolar indígena fez dela atualmente o agrupamento dos direitos políticos e culturais dos povos indígenas brasileiros, sendo portanto, uma modalidade de ensino inclusivo que foi reivindicada por lideranças, comunidades e professores indígenas que fizeram parte das lutas dos povos indígenas pela garantia e proteção territorial e pelo reconhecimento da diversidade sociocultural, específicas da constituição da cidadania indígena no Brasil (PESSOA, 2017).

Nesse sentido, ao consideramos a educação e o processo de ensino e aprendizagem no cenário indígena e de sua relação com os espaços sociais, torna-se imprescindível o debate de uma educação impregnada pela diversidade como disciplina, em que a autoimagem do povo indígena seja afirmada e revitalizada (SANTOS, 2018).

Em resposta à experiência histórica do período escravista, a educação mostrouse um caminho fértil para a reprodução dos valores sociais e/ou civilizatórios das várias etnias indígenas e de seus descendentes (RODRIGUES, 2016). No entanto, as mazelas e a aniquilação física, moral humana e cultural forjadas ao longo de nossa história não impediram as populações indígenas de promover a continuidade de sua cultura no sentido mais amplo, bem como o ensinamento de suas visões de mundo.

Em sua figura individual e em suas coletividades a identidade dos povos indígenas foi preservada como patrimônio da educação. Apesar das precárias condições de sobrevivência ainda enfrentadas, a relação com a ancestralidade e a mitologia indígena, e com os valores nelas representados, permitiu a dinamicidade da cultura e do processo de resistência das diversas comunidades indígenas (RODRIGUES, 2016).

O estado brasileiro tem uma responsabilidade histórica pelo escravismo e pela marginalização econômica, social e política dos descendentes dos índios, que persiste em tempos contemporâneos. O racismo e as práticas discriminatórias disseminadas no cotidiano brasileiro, por exemplo, não podem representar e ser justificados simplesmente como uma herança do passado (CHICARINO, 2017).

Outra responsabilidade do Estado, atuando nesse âmbito, é debater e elaborar estratégias de enfrentamento da dinâmica das relações raciais no Brasil. A admissão dessas responsabilidades históricas constitui o primeiro passo para a construção e a implementação do plano de ação do Estado brasileiro, com intuito de instrumentalizar e colocar em prática 
resoluções, em especial as voltadas para a educação, quais sejam:

- Igual acesso à educação para todos e todas na lei e na prática.

- Adoção e implementação de leis que pró́bam a discriminação baseada em raça, cor, descendência, origem nacional ou étnica em todos os níveis de educação, tanto formal quanto informal.

- Medidas necessárias para eliminar os obstáculos que limitam o acesso de crianças à educação.

- Recursos para eliminar, onde existam, desigualdades nos rendimentos educacionais para jovens e crianças.

- Apoio aos esforços que assegurem ambiente escolar seguro, livre da violência e de assedio motivados por racismo, discriminação racial, xenofobia e intolerância correlata.

- Estabelecimento de programas de assistência financeira desenhados para capacitar todos os estudantes, independentemente de raça, cor, descendência, origem étnica ou nacional a frequentarem instituições educacionais de ensino superior (CAVALLEIRO, 2006, apud CHICARINO, 2017).

As campanhas realizadas pelo movimento indigenista possibilitam ao Estado brasileiro formular projetos no sentido de promover políticas e programas para a população indígena e valorizar a história e a cultura desse povo por meio da estruturação de uma política nacional de educação calcada em práticas antidiscriminatórias (CHICARINO, 2017).

As populações indígenas que passaram pelos primeiros contatos com os portugueses, vivenciaram um processo de reconfiguração de sua história de vida para adaptação ao novo mundo, cujas marcas serviram de base para a criação de estratégias de sobrevivência (AFONSO, 2016).

A fuga dos trabalhadores escravizados, a conquista de territórios para a formação de tribos materializa as formas mais reconhecidas de luta da população indígena escravizada. Nesses espaços, as populações indígenas abrigaram-se, tentaram manter sua religião emblemática, onde a cosmovisão fundamentava-se no animismo $^{1}$ e elaboraram novas maneiras de organização social, bastante distintas da organização de origem (AFONSO, 2016).

Diante disso, cabe, portanto, ligar essas experiências e essa diversidade ao cotidiano escolar, convertendo-as em conhecimento para todos os atores envolvidos com o processo de educação, em especial professores e alunos. O silêncio da escola sobre como se dá as dinâmicas das relações étnicas no dia a dia brasileiro tem permitido a transmissão aos alunos de uma pretensa hegemonia (AFONSO, 2016). 
Essa atitude permite que cada um construa, a seu modo, um entendimento muitas vezes estereotipado do outro que lhe é diferente.

A expressão 'negociação cultural' remete às relações de poder, ao domínio e orientação intelectual e, inclusive, comportamental, que uma classe exerce sobre outra. Justamente por isso a educação, partindo das diferenças humanas e culturais, de como elas se inter-relacionam, mediante o conflito ou o equilíbrio, assume o papel de estimular o aluno a ver o mundo a ver o outro, primeiro como seu par, com quem convive em sociedade, e que esse outro, ainda que lhe seja igual, porque humano, com mesmos direitos e deveres, carrega dentro de si uma identidade, uma gama de conhecimentos, de pensamentos, que pode transformar o mundo e que, portanto, deve ser respeitada (LAMEGO E SANTOS, 2019).

A discussão em torno do termo 'multiculturalismo' entendido, em geral como a luta de "grupos sociais subalternizados e marginalizados pela elite hegemônica, buscando reconhecimento e valorização dos sujeitos socioculturais que compõem grupos minoritários" (LAMEGO E SANTOS, 2019, p. 11), tem forte relação com o movimento negro no mundo. Entretanto, outros grupos como mulheres e índios, assim como os negros tentaram reivindicar "perante as autoridades políticas seus direitos e deveres como cidadãos" (GALVÃO; LACERDA，2018, p. 143). Nesse contexto, o movimento indígena, o movimento trabalhista, o movimento feminista e o movimento LGBT tiveram de lutar, em muitos casos com a própria vida de seus militantes, tendo seus próprios corpos violados, para que essa força essencial que tem dentro de si seja, ao menos, respeitada. Não por coincidência, o multiculturalismo nasce com e nessas lutas de minorias sociais (CHICARINO, 2017). As minorias ainda tem muitas lutas a travar, porque toda a exploração teórico-conceitual aqui desenvolvida não encontra plena concretude na realidade, de modo que existem ainda desafios, a saber:

- Necessidade de desconstrução dos paradigmas preconceituosos, monoculturais e etnocêntricos das práticas escolares, o que exige o combate à naturalização dessas práticas, que vão desde as políticas públicas aos conteúdos escolares.

- Articulação entre igualdade e diferença nas políticas e práticas educativas, buscando o reconhecimento das diferenças de conhecimentos, saberes e práticas dos grupos sociais, mediados pelo paradigma da educação para todos, emergente especialmente a partir dos anos 1990.

- Resgate das identidades culturais individuais e coletivas. 
- Promoção de experiências de interação entre culturas, com o objetivo de relativizarmos a nossa cultura e nos colocarmos perante os outros de forma respeitosa, reconhecendo-os como portadores de sentidos, de uma cultura, mas não apenas como pequenos momentos de interação, e sim um projeto em que esta ocorra em caráter sistemático.

- Empoderamento dos atores sociais historicamente menos privilegiados, ou mesmo discriminados, abrindo possibilidades para que sejam sujeitos da sua vida.

\section{CONCLUSÃO}

Deparamo-nos com a multiculturalidade em nosso dia a dia e, especialmente, nos espaços coletivos, por exemplo, nas escolas, onde existem cada vez mais pessoas e grupos de culturas diversas. Pensamos que esse fato é um enriquecimento comum, porque aprendemos a cooperar, a conviver e a compreender a vida também no horizonte do outro, quando esses lugares se tornam espaços de e para todos, cumprindo ainda um papel de inclusão de minorias.

A escola inserida em um contexto mais amplo, ou seja, no interior de uma comunidade, de uma sociedade, configura um local por excelência para a produção de
- Formação para uma cidadania aberta e interativa, capaz de reconhecer as assimetrias de poder entre os diferentes grupos culturais e de trabalhar os conflitos e promover relações solidárias (CANDAU, 2008, apud CHICARINO, 2017).

Essas bandeiras de lutas, por assim dizer, devem ser assumidas por todo educador, por toda família e por todo estudante, uma vez que elas constituem um projeto de ação, de humanidade, mais do que um projeto simplesmente educativo.

relações de aprendizagem, nomeadamente, da aprendizagem cultural.

Pensemos a perspectiva intercultural como uma extensão ao multiculturalismo, como algo que surge a partir deste. Essa perspectiva vai além da convivência entre culturas, pois abrange aspectos como a identidade, o respeito enquanto caminho para o bem comum. Viver em conjunto, apesar das tensões conflituosas que podem emergir, provoca o entrecruzamento de múltiplas tradições, chegando ao ponto de se tornar espaço comum.

É preciso estar atento a esses cruzamentos para, então, estimular os lugares de reencontro, pois as tradições, assim como a convivência, não são unicamente conflituosas. 
$\mathrm{Na}$ sociedade observamos determinados comportamentos, tais como: códigos e suas respectivas apropriações; expectativas e emoções subjacentes a esses comportamentos habituais; artefatos produzidos e utilizados; instituições políticas, sociais e culturais em funcionamento ou sendo repensadas e atualizadas para novas necessidades; e finalmente formas várias de relações humanas. Isso é cultura, é a vida social acontecendo.

O multiculturalismo abre espaço para a vontade de cada indivíduo e de cada grupo em mostrar sua identidade aos outros; e todos, em conjunto, promovem e alcançam o interculturalismo, que pelo diálogo, pela troca de conhecimentos,

\section{REFERÊNCIAS}

ABUL-EL-HAJ, M. F.; FIALHO, L. M. F. Formação docente e práticas pedagógicas multiculturais críticas. Revista Educação em Questão. Natal, v. 57, n. 53, p. 1-27, e17109, jul./set., 2019.

\section{AFONSO, Germano Bruno. Ensino} deHistória e Cultura Indígenas. Curitiba: Intersaberes, 2016.

ARAÚJO, N. B.; MOTA, C. M. A. Profissionalidades e práticas docentes multiculturais: lugares possíveis? Org. e Demo, Marília, v. 18, n. 2, p. 69-82, jul./dez., 2017.

BAVARESCO, P. R.; TACCA, D. P. Multiculturalismo e diversidade cultural: práticas e comportamentos, integra essas vontades com o objetivo de promover a compreensão e a tolerância entre os indivíduos de origens diversas.

Para que isso se concretize é preciso que a educação cumpra seu papel e, em seu conjunto de estratégias organizacionais, curriculares e pedagógicas, promova a igualdade racial e elimine as formas de discriminação e opressão, quer individuais quer institucionais. A educação multicultural, mais especificamente, deve promover a partilha, a valorização e o respeito pela diversidade das culturas representadas na turma, na escola e na comunidade, assim como combater os preconceitos e as discriminações étnicas.

uma reflexão. Unoesc e Ciência - ACHS, Joaçaba, v. 7, n. 1, p. 61-68, jan./jun., 2016.

CANDAU, V, M. F. Ser professor/a hoje: novos confrontos entre saberes, culturas e práticas. Educação. v. 37, n. 1, enero-abril, p. 33-41. Pontifícia Universidade Católica do Rio Grande do Sul, porto Alegre, 2014.

CILIATO, F. L. G.; SARTORI, J. Pluralidade cultural: os desafios aos professores em frente da diversidade cultural. Revista Monografias Ambientais - REMOA, v. 14, p. 65-78, 2015.

CHICARINO, T. Diversidade cultural. Pearson Education do Brasil, São Paulo, 2017. 
COUTINHO, C.; RUPPENTHAL, R. Cultura e educação científica: alternativas pedagógicas para inserção do multiculturalismo na formação inicial de professores. Revista Signos, Ensino, Humanidades. Lajeado, ano 37, n. 1, 2016.

DELMONDEZ, P.; PULINO, L. H. C. Z. Sobre identidade e diferença no contexto da educação escolar indígena. Psicologia e sociedade, 26 (3), p. 632-642, 2014.

DOMINGUES, M. P. B.; COTA, F. S. A diferença na sala de aula: reflexões sobre a história indígena escolar e a história de educação inclusiva. Revista do LhistaLaboratório de Ensino de História e Educação. n. 1, v. 1, julho/dezembro, 2014.

FIGUEIREDO, J. A. et al A "inclusão" do indígena na escola. Revista Panorâmica, on-line. Barra das Garças - MT, v. 23, p. 76-86, jul./dez., 2017.

FREITAS DE LIMA, E. A construção de práticas pedagógicas inter/multiculturais no ensino fundamental e os saberes docentes. Revista Diálogo Educacional, v. 14, n. 42, mai./ago., p. 395-414, 2014.

GALVÃO, C. M. P.; LACERDA, M. C. Multiculturalismo em educação. Revista Saberes, UNIJIPA - JI - Paraná, v. 8, n. 1, jan./jun., 2018.

GONÇALVES, J. P.; OLIVEIRA, E. L. Uma diversidade cultural e relações de gênero em uma escola indígena sul-matogrossense. Revista Educação e Pesquisa, São Paulo, v. 44, e1851444, 2018.

GRUBITS, S. Mulheres indígenas brasileiras: educação e políticas públicas. Psicologia e Sociedade. 26(1), 116-125, 2014.

KAIAPÓ, E.; BRITO, T. A pluralidade étnico-cultural indígena no Brasil: o que a escola tem a ver com isso? Caicó, v. 15, n. 35, p. 38-68, jul./dez. 2014. Dossiê Histórias Indígenas.

LAMEGO, C. R. S.; SANTOS, M. C. F. Formação de professores e educação intercultural: concepções e práticas de licenciados sobre diversidade cultural na educação básica. Contexto \& Educação. Editora Unijuí, Ano 34, no 108, Mai./Ago. 2019.

LIMA, N. F. et al. Educação e interculturalidade: a formação dos professores indígenas. Revista Humanidades e Inovação. v. 4, n. 4, 2017.

LISBOA GROSS, D. G. et al. Reflexões acerca da etnicidade e diversidade cultural na BNCC e no PNE. Revista

Humanidades e Inovação. v. 6, n. 18, 2019.

MICHALISZYN, M. S. Educação e Diversidade. Revista Intersaberes, Curitiba, v. 12. 2014.

MONTEIRO, F. M. A; FONTOURA, H. A.; CANEN, A. Ressignificando práticas de ensino e de formação docente: contribuições de narrativas, diálogos e conferências. Revista Educação Pública. v. 23, n. 53/2, p. 637-654, mai./ago., 2014. MOSER, A. C. Educação e Diversidade. Santa Catarina, Editora: Uniasselvi, 2017.

NAZARENO, E.; ARAÚJO, O. C. G. Reflexões em torno do tema contextual "etnicidade e diversidade cultural".

Articul. Constr. Saber, Goiânia, v. 2, n. 1, p. 116-132, 2-17.

PEREIRA, P. F. S.; NETO, J. S. Um pouco além dos territórios: o direito fundamental dos povos indígenas a uma educação diferenciada. Revista da Faculdade de Direito - RFD -UERJ, Rio de Janeiro, n. 31, jun, 2017. 
PESSOA, H. C. C. Narrativas de professores indígenas sobre o cotidiano escolar. Revista Ensino Interdisciplinar. v. 3, n. 08, VERN, Mossoró, RN, maio/2017.

RODRIGUES, W. O ambiente escolar e a valorização cultural indígena. Periferia: Educação, Cultura e comunicação. V. 8, n. 1, jan.-jun., 2016.

SANTOS, M. D. A educação escolar indígena na pós-modernidade. Revista Panorâmica, v. 25, 2018. (Edição Comemorativa).

SANTOS, R. B.; SERRÃO, M. C.

Educação escolar indígena em escolas urbanas: realidade ou utopia? Revista Eletrônica Mutações - RELEM, jul-dez, 2017.

SILVA, A. F. et al. Educação Indígena. Revista Maiêutica. Indaial, v. 4, n. 1, p. 65-74, 2016.

SILVA, A. R.; FREITAS, M. C. S. A institucionalização da educação escolar indígena no Brasil. Revista Científica
Vozes do Vales - UFV. JM, MG - Brasil, n. 06, ano III-10/2014.

SILVA, J. B. Formação, pesquisa e práticas no contexto da educação escolar indígena: as ações do PIBID diversidade no povo Xucuru do Ororubá. Ñanduty. v. 5, n. 7, 2017.

SOBRINHO, R. S. M.; SOUZA, A. S. D.; BETTIOL, C. A. A educação escolar indígena no brasil: uma análise crítica a partir da conjuntura dos 20 anos de LDB. Unisul, Tubarão, v.11, n. 19, p. 58 - 75, Jan/Jun 2017.

SOUZA, R. S.; SILVA, D. G.; GONÇALVES, T. P. N. R.

Multiculturalismo e educação: o espaço da gestão. Revista Caminhos da Educação: diálogos, culturas e diversidades. CAEDU/UFPI, Teresina, Brasil, v. 1, p. 154-174, janeiro/abril, 2019.

VOLKMER, M. S. et al. Educação e diversidade cultural: culturas indígenas e africanas na sala de aula. Revista de História e Geografia. Santa Cruz do Sul, v. 17, n. 02, p. 52-63, jul./dez. 2015. 